\title{
Evaluation of Next Generation Healthcare Services: Wearable Technology Products
}

\author{
İffet PALA ERCAN, H. Kübra DOLAP YILDIZ and Sena SEMIZOĞLU
}

\begin{abstract}
Developments in medical technologies, especially in the last quarter of this century, have enabled the development and availability of a large number of diagnostic, therapeutic and rehabilitation devices, and significant success has been achieved in the treatment of certain diseases although medical science has almost a history as close to human history poosible.

In healthcare service, it is essential to provide the best care that fits the needs of the individual as much as possible. Until recently, people had to be physically in the same place as the service provider in order to benefit from professional healthcare. As a result of this situation, medical sector has been faced with challenging factors such as access, quality and cost. However, in line with the advances in technology in health services where natural and cheap techniques have been used for many years, the way and quality of diagnosis and treatment services have been changed and new generation health fields have been created.

One of the new generation healthcare services that technology offers us is wearable technology products. In general, the shift of health services from hospitals to personal areas of the patient has increased the use of wearable technology products in medicine and healthcare. In this study, the general situation of healthcare services has been examined and wearable technology products developed for this field have been revealed. The aim of this study; is to reveal and discuss the development of healthcare services from past to present with developing technology.
\end{abstract}

Keywords - healthcare service, medical devices, medical sector, wearable technology

\section{INTRODUCTION}

In the past decades investments and expectations about healthcare industry shifted into early diagnosis, monitoring health condition, healthy lifestyle and common life quality [1]. This shift can be explained as a consequence of paradigm change from medical care approach which is diagnostic and treatment oriented to health care approach in which being and staying healthy has more importance than just treating illnesses. Health policies around the world are altering from treatment oriented to a preventive care approach. Also it can be argued that preventing diseases is economically more beneficial than treating illnesses.

With recent technological developments it became possible

Manuscript received Nov. 20, 2019.

İffet PALA ERCAN Istanbul Technical University, Faculty of Architecture. Beyoğlu / Istanbul.

H. Kübra DOLAP YILDIZ Istanbul Technical University, Faculty of Architecture. Beyoğlu / Istanbul.

Sena SEMIZOGLU Istanbul Technical University, Faculty of Architecture. Beyoğlu / Istanbul. to transfer treatment and care services from hospitals to homes and maintain a balance between service quality and costs in healthcare industry [2]. Healthcare service technologies help getting better results in the field in two ways. Firstly, they enhance life quality and prolong life expectancy therefore directly raise health outcomes. Secondly, these new technologies affect healthcare industry positively by decreasing the duration of stay at hospitals and costs [3].

One of the primal products in new generation healthcare services provide is wearable technology products. Wearable technologies can be used for diagnostics, treatment and rehabilitation issues.

In this study healthcare services and medical sector is investigated and the importance of wearable technologies in new generation healthcare services is discussed. Literature review method is used to gather and analyze data.

\section{OVERVIEW OF MEDICAL DEVICE INDUSTRY AND HOME HEALTHCARE SERVICE}

Providing and performing healthcare services contains several techniques, equipment (tools, devices, appliances etc.) and drugs [4]. Within this diversity, the medical products sector, which has become a high added-value industry branch, constitutes an important input of health services [2,5].

For many years healthcare industry used natural and cheap techniques, but along with technological developments first basic technological products become part of this sector; and in later years both the techniques and supporting technologies changed constantly and rapidly and these techniques and technologies become more complicated and variable $[2,6,7]$.

World Health Organization accepts medical products in the context of life sciences and healthcare services as an important component for "Availability, Accesibility, Appropriateness, and Affordability" [8]. In this regard, medical device industry with its rapid growth speed is one of the most dynamic sectors of economy, and the economic value of this sector attracts both local and global corporates [5].

When global economic developments are investigated medical devices arise as one of the most rapidly growing fields and stand as in an important position for innovation ecosystem. Sector is named as an high technology sector according to OECD's 2011 ISIC Rev.3 classification [2]. This structure with its raising life quality and improving health outcomes nature [3] - is used for maintaining wellness, delaying and avoiding initial terms of diseases, and providing solutions and treatments for a variety of health problems [9]. 
Even though medical sciences has centuries long background, with progresses in medical technologies especially in this century and past decades, make it possible to develop special devices that can be used in diagnostics, treatment and rehabilitation, which have great contribution in eliminating certain diseases. Technological developments in the last few decades shaped healthcare sector with its effects on the service features and quality of diagnostics and treatment [2]. While initial healthcare services are provided in hospitals, industrialized countries provide this services in-situ which resulted in a shift in healing environments from hospitals to homes [10].

In healthcare services, it is essential to provide specialised care regarding to individual needs. Until quite recently it was required for individuals to be in the same physical environment with the professionals to get professional healthcare services. As a consequence there was mismatched requirements such as low spaces for in-patient treatments and having too many patients for each medical personnel, and also it meant that patients should accept these mismatched conditions. Aging population along with increasing rates of their chronical diseases such as diabetes, coroner heart and respiratory insufficiency need to visit hospitals more. Similarly, this disadvantaged group may have limited access to healthcare services due to reduced mobility capabilities in later years. Therefore, even these diseases cannot be fully treated, developing at home healthcare services has become an important issue to raise life quality and experiences of these patients by allowing them to get the service they need at home and track their own health etc. [11]. Also at home healthcare services are becoming a part of government policies [5]. Regarding to these factors researchers, policy makers and healthcare workers are investigating innovative solutions such as mobile healthcare services, e-health services and tele-medicine tools; and wearable technologies stand as an important area of these solutions.

\section{NEW GENERATION HEALTHCARE SERVICES: WEARABLE TECHNOLOGY PRODUCTS}

After 400 years of medical services being provided at hospitals, industrialized countries are headed into providing these services at where patients need it [10]. Health sector face problems about quality, accessibility and cost daily. To deal with these obstacles these factors should be minded: decreasing healthcare costs without sacrificing high levels of service quality, dividing healthcare investments more in preventing and preserving than in treatment, reaching out more patients, controlling hospital stay duration, aging population and chronical diseases [12]. In recent years investments and expectations in healthcare are headed into early diagnosis of diseases, monitoring health conditions, healthy life style and common health quality [1]. Expectations of individuals about getting better medical services for themselves and their relatives

With the help of technology, managing service quality and costs in health sector is possible [13]. One of the product branch new developing technologies brought into health sector is wearable technology products. Wearable technology is adopting and implementing technology into daily wearables such as clothing and accessories. Wearable technology - as one of the biggest advancements in 21st Century - emerged when fashion and technology are combined [14]. Different types of wearables can be used in different parts of the body as in Fig.1.

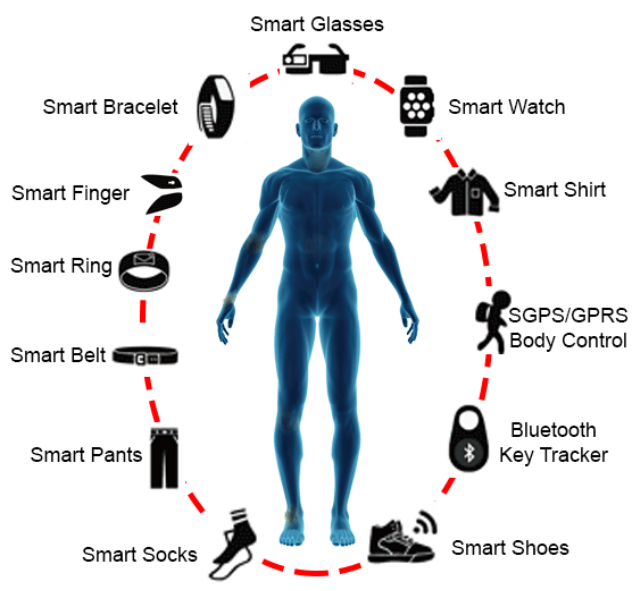

Fig. 1. Different types of wearable technology [15]

Wearables made with products and fabrics embedded with receptor sensors, are able to gather allowed data and perform defined tasks [16].

Wearable health technologies are defined with different concepts in different research. Leonhardt [17] named these technologies as 'personal healthcare tools' and defined as smart and wearable tools that support patients in home environment. Lymberis and Davis (2007) named these technologies as "wearable health systems" and "smart biomedical clothing" by supporting and giving examples of these technologies in their work [18].

The interest of medical community into these wearable technologies can be investigated in two main causes. First is the ability to gather and monitor data for long periods which makes it possible to diagnose and treat diseases earlier. This ability is associated with decreasing healthcare costs, at the same time it holds the possibility of increasing health service quality by gathering personal data that helps defining the treatment process [19]. Second is overcoming the inadequacy of determining rare cases with devices such as Holter [20]. Few of the advantages about using wearable technologies over other medical devices can be listed as such: ergonomic structure for easy carrying, fast interaction, ease of use and especially freedom of movement. And these features take place in health sector [13].

When wearable technologies which are used in medical and healthcare sector in recent years, and that has importance in new generation health services are investigated, it can be seen that research is mostly conducted as academic works.

In general terms providing health services in personal spaces rather than hospital caused enriched the areas of wearable technologies use in medical and health services. With 
technological developments traditional products which are also used in medical services become innovative products.

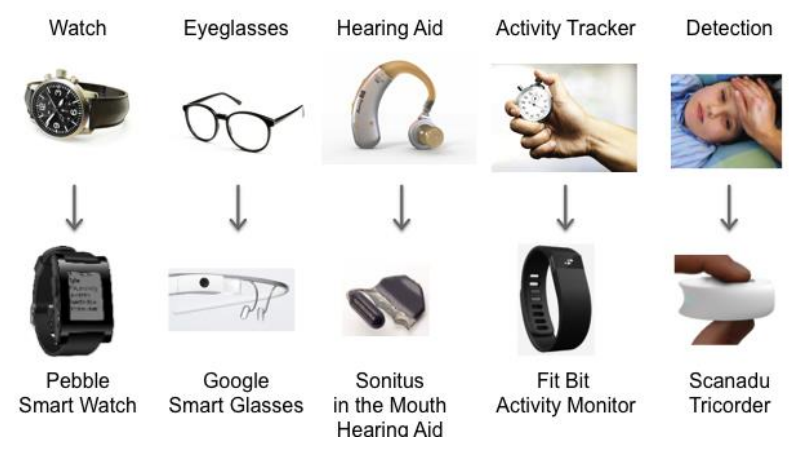

Fig. 2. From traditional products to innovative products in healthcare service [URL-1]

Medical smart clothes are designed to gather varying data from human body, detect changes and react when needed. When contact duration between the body and the clothing is taken into consideration, these smart clothes can gather more personal data. One of the first smart clothing - Smart Shirt - produced to gather bodily data can be seen in Figure 3 .

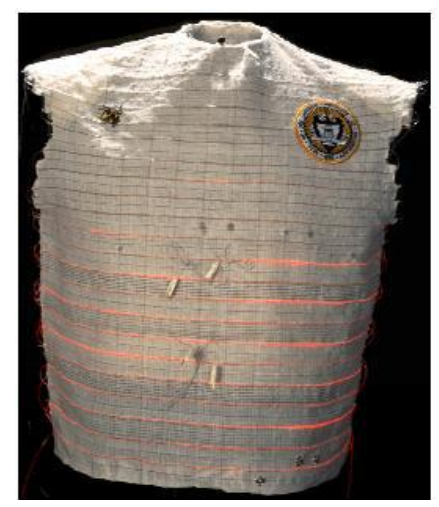

Fig. 3. Clothes Detecting Vital Signs(Smart Shirt) [21]

Smart tattoos - which can also be counted as wearable technologies - can be used as touch-operated surfaces that can be connected to mobile device interfaces, or as indicators that show body temperature and varying body indexes, or electronic identities [22]. Smart tattoos make it possible to command smart devices from the arm, and with temporary tattoos this connection can be removed on demand. These tattoos invert skin into smart touch panels, and with NFC it became possible use these tattoos in accordance with supporting devices [URL-2].

In the last decade developments and initiatives in wearable devices are predominantly made in fitness sector, there are several initiatives in medical sector. Özkara et al [23] conducted a research using wearable technologies to monitor data in electrocardiography field. Lara et al, in their 2012 study, worked on recognizing daily tasks such as walking, running, sitting, going up and down in stairs with the help of a sensor mounted on chest. In 2013, Trabelsi et al, used three accelerometers mounted on users' left ankles, chest and leg to estimate the physical action they are performing. The developments in wearable technologies are mostly supported by health industry as it deals with tracking daily activities of individuals and fall detection [24]. Wearable smart devices developed for babies enables parents to control and monitor the comfort and health situations of the babies at all times. A smart device developed for babies can be seen in Figure 4. Owlet by Jacob Colvin from Brigham Young University can be counted as a landmark work. This product is used for babies to monitor their conditions such as heart rate, rhythm and body temperature from smart mobiles [25].

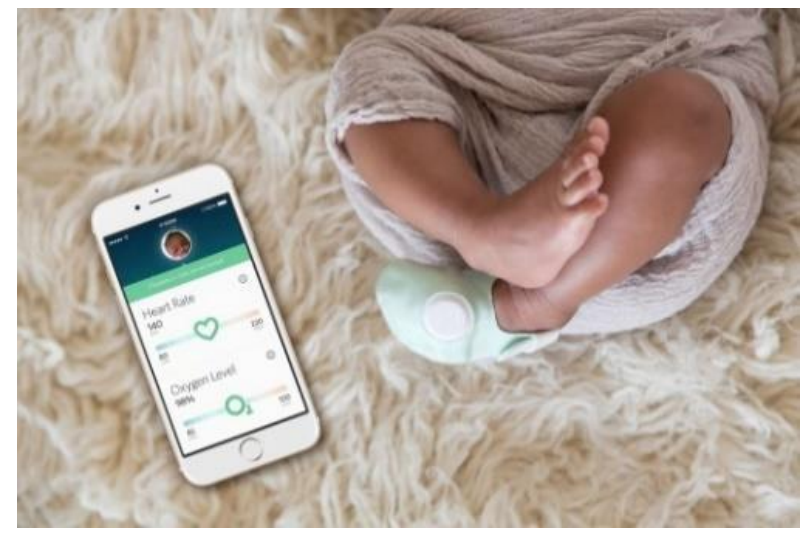

Fig. 4. Example of Wearable technology products for babies

When the nature of medical services - as it does not only stand as a daily need, but also an important factor in economy is considered wide usage of wearable devices is not a surprise [26]. Similarly to other sectors several factors affect the market growth in the health sector. Raising levels of health awareness, increasing medical service costs and personal preferences that shifted from person-to-person interaction to digital networks, support wearable developments in health sector [27]. Advantages such as monitoring a disease constantly and regularly, instant medical intervention, informing authorised medical agents and products that support healing processes after surgeries have great contribution in raising medical smart wearables in the market [28].

\section{CONCLUSION}

Wearable technology or wearables are small electronic devices embedded into items that attach to the body and passes computational capability. Devices can be integrated into clothing, recognizable personal accessories or additional devices. They record user's movements, physical data, location or status, habits, psychological data by using various sensors.

Wearable technologies bring the opportunity of obtaining information about individuals' general health condition without visiting health institutions. Doctors' desire to constantly monitor their patients' conditions outside the hospital, increase in self-care applications at home, and raising levels individuals' 
awareness to track their conditions promote the need for wearable technologies [29]. These technologies includes leading tools for gathering, processing and transferring personal health data.

Medical device industry is a biotic sector regarding to its relation with healthcare systems and therefore it is a must for this industry to become interdisciplinary [2]. When worldwide examples are investigated it can be seen that interdisciplinary doctor-patient experiences that combine medical, engineering, management and design actors contain innovative solutions where the sources are used more efficiently [2]. Interdisciplinary work on medical device development has been determinative and effective especially after 1960s. In this regard even though it is a relatively young industry, collaborations between specialised designers, engineers and medical professionals is needed for developing wearable technologies [5].

Regarding to the investigated works, use advantages of wearable technologies over other devices can be listed as such mobility as a result of their ergonomic design, fast interaction, ease of use, and freedom of movement; while possible problems can be listed as such: lack of current infrastructure (internet bandwidth, prevalence), social concerns, ethical factors, technical skills and compatibility and high costs. While there are several studies in home healthcare services field, there are still many questions to be investigated. According to Chamberlain the biggest issue is how matters such as trust, security, property, identity and aesthetics are dealed while healing environments shift from hospital to home [5]. As a result of being a relatively new technologies there are still some risks and dangers of wearable technologies. In upcoming studies it is foreseen to eliminate these dangers and risks for healthcare services, and increasing use of wearable technologies in medical sector.

\section{REFERENCES}

[1] A. Lymberis and A. Dittmar, Advanced WearablevHealth Systems and Applications - Research and Development Efforts in the European Union. IEEE Engineering in Medicine and Biology Magazine, 26(3), 29-33, 2007.

https://doi.org/10.1109/MEMB.2007.364926

[2] M. Kiper, "Dünya'da ve Türkiye'de Tıbbi Cihaz Sektörü ve Strateji Önerisi". Türkiye Teknoloji Geliştirme Vakfı, 2013. Available: http://www.seis.org.tr/docs/daha-cok-uretmeliyiz/tibbi-cihaz-sektoru-str ateji-onerisi.pdf

[3] F. R. Lichtenberg., M. Tatar \& Z. Calışkan, "The effect of pharmaceutical innovation on longevity, hospitalization and medical expenditure in Turkey,1999-2010". Health Policy, 117(3), 1-41, 2014. https://doi.org/10.1016/j.healthpol.2014.06.002

[4] Ş. Demirci, "Giyilebilir Teknolojilerin Sağlık Hizmetlerine ve Sağlık Hizmet Kullanıcilarına Etkileri", Journal of Social Sciences of Mus Alparslan University, 6(6), 985-992, 2018

[5] Y. Soylu and B. K. Şalgamcığlu. (October 2016) "Medikal tasarım sektörünün bugünü ve geleceği: Öne çıkan tasarımlar", Sağlık Düşüncesi ve Tip Platformu, Available: http://www.sdplatform.com/Dergi/959/Medikal-tasarim-sektorunun-bug unu-ve-gelecegi-One-cikan-tasarimlar.aspx

[6] S. Mollahaliloğlu, H. Arı, H. Öncü, H. Gürsöz, "Türk Sağlık Sektöründe Tıbbi Cihazların Sayısal Durumu, Bölgesel Dağılımı ve OECD Ülkeleri İle Karşılaştırmalar",2009, Hacettepe Sağlık İdaresi Dergisi,Cilt:12, Sayı:1
[7] A. E. Sargutan, "Sağlık Teknolojisi Yönetimi”, Hacettepe Sağlık İdaresi Dergisi, 8(1), 113-144, 2005.

[8] WHO, "Medical Devices: Managing the mismatch: an outcome of the priority medical devices Project", 2010.

[9] National Center for Health Statistics, "Health, United States, 2009: With Special Feature on Medical Technology", Hyattsville, 2009.

[10] R. Barnard and J. T. Shea, "How wearable technologies will impact the future of health care. In Lymberis A. and Rossi D. (eds.) Wearable eHealth Systems for Personalised Health Management", pp: 49-55. IOS Press, Amsterdam, 2004

[11] B. Şener, G. Hasdoğan and O. Pedgley, "Yaşlılar İçin Evde Sağlık Çözümleri”, UTAK 3. Ulusal Tasarım Araştırmaları Konferansı, pp: 201-217, 2018.

[12] S. Park and S. Jayaraman, Enhancing the Quality of Life through Wearable Technology. IEEE Engineering in Medicine and Biology Magazin, 22(3): 41-48, 2003 https://doi.org/10.1109/MEMB.2003.1213625

[13] S. Aydan and M. Aydan, "Sağlık Hizmetle- rinde Bireysel Ölçüm ve Giyilebilir Teknoloji: Olası Katkıları, Güncel Durum ve Öneriler", Hacettepe Sağllk İdaresi Dergisi,19 (3)., 325-342, 2016

[14] Yetmen, G., "Giyilebilir Teknoloji”, Ulakbilge Sosyal Bilimler Dergisi,5 (1), 275-289, 2017 https://doi.org/10.7816/ulakbilge-05-09-13

[15] G. A. Oliveira, "Um modelo para gerenciamento de históricos de contextos físiológicos," M.S. thesis, Programa Integrado de Pós-graduação em Computação Aplicada, Universidade do Vale do Rio dos Sinos, São Leopoldo, Brazil, 2016.

[16] S. F. Çakır, A. Aytekin, and F. Tüminçin, 'Internet of Things and Wearable Techologies', Journal of Social Research and Behavioral Sciences, 4(5): 84-95, ISSN: 2149 - 178X, 2018

[17] S. Leonhardt, Personal Healthcare Devices. In Mukherjee et al. (eds.) Am I ware Hardware Technology Drivers of Ambient Intelligence Philips Research Book Series Volume 5 pp: 349-370 , 2006, Springer, Netharlands. https://doi.org/10.1007/1-4020-4198-5_17

[18] Ö. H. Kılıç, Giyilebilir Teknoloji Ürünleri Pazarı ve Kullanım Alanları, Aksaray Üniversitesi İktisadi ve İdari Bilimler Fakültesi Dergisi, 9 (4) : 99-112, 2007

[19] A. Belsi, E. Papi, E, A. H. McGregor, ( "Impact of Wearable Technology on Psychosocial Factors of Osteoarthritis Management: A Qualitative Study", BMJ Journal, 6 (2), 1-7, 2015 https://doi.org/10.1136/bmjopen-2015-010064

[20] P. Bonato, Advances in Wearable Technology for Rehabilitation. Studies in Health Technology and Informatics 145: 145-159, 2009

[21] L. Gregorio, V. Custodio, and J. I. Moreno, "LOBIN: E-textile and wireless-sensor-network-based platform for environments." Information Technology in Biomedicine, IEEE Transactions on 14.6 , 1446-1458, 2010

https://doi.org/10.1109/TITB.2010.2058812

[22] S. Sezgin, "Eğitimde Giyilebilir Teknolojiler: Fursatlar ve Eğilimler", Mehmet Akif Ersoy Üniversite- si Eğitim Fakültesi Dergisi,40, 405-418, 2016 https://doi.org/10.21764/efd.72734

[23] O. Özkaraca, A. H. Işık, ve İ. Güler, Detection, real time processing and monitoring of ECG signal with a wearable system. In Innovations in Intelligent Systems.

[24] İ. Pala, Ş. Timur, Giyilebilir Teknoloji Uygulamalarında Ürün ve Moda Tasarımı Yaklaşımları Arasındaki Farkın İncelenmesi', 3'rd International Symposium on Industrial Design \& Engineering, Erciyes University, Kayseri, Turkey, 2018

[25] K. Boyacıoğlu, "Global Ekonominin Yeni Trendi: Giyilebilir Teknoloji", 2015.

[26] S. Safavi, Z. Shukur, "Conceptual Privacy Framework for Health Information on Wearab- le Device, PLoS ONE, 9(12) , 2014 https://doi.org/10.1371/journal.pone.0114306

[27] M. Lim, "Wearable Technologyand Sleep Di- sorders" San Mateo Country Physician, 5 (6), 7-9, 2016

[28] F. Patlar Akbulut, and A. Akan, "Akıllı Giyile- bilir Hasta Takip Sistemleri", Tip Teknolojileri Ulusal Kongresi", 15-18 Ekim TipTekno15 Muğla, 440-443, 2016 
[29] E. Bostanc1, Medikal Alanda Kullanılan Giyilebilir Teknolojiler: Uygulamalar, Karşılaşılan Sorunlar ve Çözüm Önerileri. In: Tıp Teknolojileri Ulusal Kongresi, Muğla, 549-552, 2015.

url - 1 (https://volersystems.com).

url- 2. (www.webtekno.com).

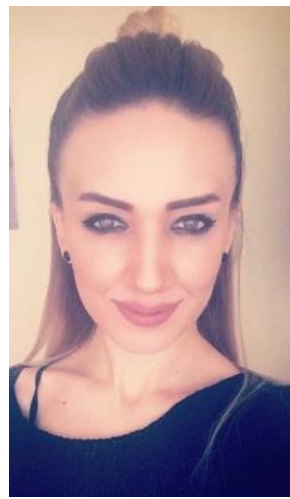

BIOGRAPHIES

department.

Candidate): She was born in 1988 in Kayser /Turkey. After graduating from Erciyes University - Textile Engineering in 2010, she received her master's degrees from Erciyes University - Textile Engineering Department with her study on Design Exoskeleton for Dentist and the other one is from İstanbul Technical University - Industrial Product Design Department with her study on composite materials in product design. Currently, she continues her studies on relationship wearable technology products and product design and in the Department of Industrial Product Design at Istanbul Technical University and is currently working as a research assistant at the same

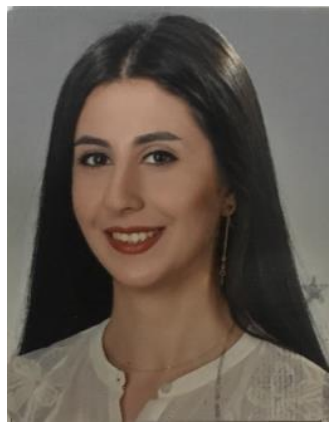

H. Kübra DOLAP YILDIZ (Ress. Asst Ph. D. Candidate): : She was born in 1989 in Eskişehir./ Turkey After graduating from Anadolu University Industrial Product Design Department in 2013 as the top student, she received her master's degree from Mimar Sinan Fine Arts University Industrial Product Design Department with her study on universal design and sustainable product design. Currently, she continues her studies on universal / inclusive design in the Department of Industrial Product Design at Istanbul Technical University and is currently working as a research assistant at the same department.

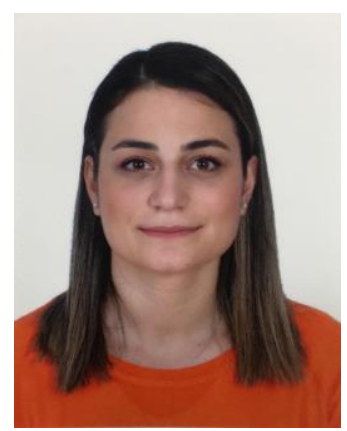

Sena SEMIZOĞLU (Ress. Asst / Ph. D. Candidate): : She was born in 1990, in Istanbul/Turkey. After graduating from Istanbul Tecnical University Interior Architecture Department in 2012, she recieved her master's degree from Istanbul Tecnical University Industrial Product Design Department with her study on the relevance of interaction design, architecture and product design. Currently she continues her studies on interaction design and human-robot interaction in the same department. She is currently a research assistant at Istanbul Tecnical University Industrial Design Department. 